e o bem estar do operário brasileiro; mas acontece que o tempo urge e, por isto mesmo, dando por palidamentejustificada e obscuramente defendida a tese proposta, concluiremos, agora, na presunção de ter esclarecido que Ruy Barbosa - em que péze a opinião reiterada do sr. Gilberto Freyre a respeito - jamais esteve "indiferente" face à Questão Social, eis que, contràriamente, sempre pôz em equação os problemas obreiros, buscando para os mesmos uma solução equidosa e justa! (Palmas).

O SR. PRESIDENTE - Antes de passar à tese seguinte, deveremos pôr em votação as conclusões do parecer apresentado pelo relator, dr. Girão Barroso, sôbre a tese do professor Dario Bittencourt - "Ruy e o Direito do Trabalho". O sr. secretário terá a bondade de ler as conclusões, para que o Congresso as tenha presentes.

O SR. SECRETÁRIO - (Lê):

"A comissão pela unanimidade de seus membros, e tendo em vista o PARECER oral apresentado pelo Relator, professor Magdaleno Girão Barroso

\title{
RESOLVE
}

A) não sòmente louvar o brilhante trabalho apresentado pelo professor DARIO BITTENCOURT, uma vez que representa uma das mais importantes contribuições ao esclarecimento que da obra de RUY BARBOSA se vem fazendo, a partir da comemoração de seu centenário;

B) como recomendá-lo à aprovação do plenário do Congresso, com o destaque previsto pelo parágrafo único do art. 13 do Regulamento, para que o seu ilustre autor tenha ocasião de especialmente explaná-lo, restaurando, assim, de público, e com reflexo na opinião nacional, a verdade a respeito da co-participação do insigne. polígrafo baiano na obra de estruturação da nossa legislação social;

C) e ainda, por fim, solicitar que seja incluído nos Anais, "que." do Congresso venham a ser publicados, encaminhando-se um exemplar à CASA DE RUY BARBOSA, para que nos seus arquivos possan figurar".

(Deixa a presidência o professor Salgado Martins, sendo subs-. tituído pelo professor Darcy Azambuja).

O SR. PRESIDENTE - Está em discussão o parecer dà Comissão. (Pausa).

Como ninguém quer fazer uso da palavra, passa-se à votação. Os srs. Congressitas que não estiverem de acôrdo, tenham a bondade
de se levantar. (Pausa). Aprovado.

\section{SESSÃO SOLENE DE ENCERRAMENTO DO CONGRESSO JURIDICO}

\author{
Realizada a 17 de agôsto de 1950
} sob a Presidência do Prof. Dr. Júlio César Bonnazzola

O SR. PRESIDENTE - Júlio César Bonnazzola - Vamos dar início à sessão de encerramento oficial do Congresso.

Tem a palavra o sr. professor Edgar Luiz Schneider.

O SR. EDGAR LUIZ SCHNEIDER - (Lendo):

A promoção dêste congresso não visou, apenas, a aproximação entre os homens do direito, senão também ao intuito de conferir, ao cabo de meio-século da Faculdade, que o ensina, os rumos nos quais se louvam seus mestres e as tendências nas quais se espelha a evolução jurídica do mundo.

Encargos dessa eminência, que tanto variam nas suas fontes geradoras, nunca terão um patrocínio, talvez, mais à feição, que entre os titulares do magistério. Não vai nisso um enaltecimento sem causa. São muitos, e todos de brios análogos, os cultores da ciência de Ulpiano, tais os legisladores, que a enriquecem, os advogados que interpretam e os juízes que a aplicam.

\section{O MAGISTÉRIO DO DIREITO}

Mas, os professôres que, nas práticas de uns e autros, buscam as provisões, valorizadas pela intuição e pela experiência, não só as coordenam, que ainda as depuram e propagam. Nessa faina diuturna, que remonta às nascentes do direito e se purifica nas suas águas perenes, em demanda da justiça, o mestre adulçora e irradia o fervor predicante.

Empossado nesses atributos, é de admitir-se, pois, que ao docente caiba, antes que aos demais, o afã de acolher as conquistas jurídicas e servir à sua difusão, entre as gerações que se sucedem.

Todavia, onde melhor o pudera, sentindo ao perto as frágoas da luta, senão ao contato do magistrado e profissionais do fôro, como familiares que são da rotação social do direito, em cuja primado assenta o destino da civilização? 
Estão todos, nesse sacerdócio, impregnados da fascinação da verdade. Assim, os advogados que, segundo Ângelo Majorana, "fazem praça da porção contida nas razões de seus clientes, os juízes que trazem a verdade completa ao âmbito de suas sentenças, e os mestres que, no campo teórico, a procuram inteira e sem limites".

Dessarte, sem custo se percebe quanto ao professor interessa a expansão do direito, à luz da filosofia e da ciência, recebendo de permeio os influxos da realidade ambiente, onde surgem e se espraiam as inovações fecundas e duradouras.

Nessa posição tocou ao magistério da antiga Faculdade de Pôrto Alegre, que o promoveu, secundada pela Ordem e Instituto dos Advogados, participar dêste congresso, tendo a honrosa presença de catedráticos ilustres, assim das cultas nações platinas como das escolas congêneres de São Paulo, Ceará, Santa Catarina e Goiás.

\section{A ORDEM JURÍDICA}

Graças ao convívio, que se estabeleceu, através de porfiados debates, nos quais surgiram e transcenderam ao plano alto da consciência jurídica as manifestações do plenário, não tardou a franquear-se, nesse encontro sugestivo, a supremacia social do direito.

Fora da órbita de passadas concepções, cujo traço mais saliente residia em confirmar sua efetividade ao âmbito nacional, eis que já agora é o direito situado entre horizontes mais amplos, que são os contornos do próprio orbe civilizado.

Reluta o espírito jurídico em assentir que os povos, integrantes da família humana, possam recìprocamente destruir-se, a pesar de tôdas as generosas franquias acumuladas, ao correr da emulação entre os homens, zelosos de servir ao engrandecimento e progresso comuns.

Porque a guerra, oriunda da avideza e do arbítrio, é a negação dêsse roteiro fraterno, ingentes são os esforços que, em conjurar ou amortecer seus golpes, aplicam e desenvolvem os paladinos da civilização.

Mas, em vão que o tem sido tanta diligência, só resta esperar do direito, como instrumento capaz de unir e aplacar, a construção da paz, sem prevenções nem temores.

Não foi outra, por certo, a intenção que serviu de esteio às $\mathrm{Na}$ ções Unidas, em cuja organização sobressaem o Conselho de Segurança e a Côrte Internacional de Justiça, regidos ambos pelos princípios de direito, abraçados pela carta de São Francisco.

Meio-século atrás, já advertia Rui Barbosa que "a grande fraqueza das civilizações mais adiantadas é a ausência duma autorida. de que, nas relações internacionais, aplique a sanção do direito".
Entretanto, o que deveras singulariza, nos seus propósitos, a entidade nascente, a par com a sua definição da paz, é a penetração desta nas inteligências, mediante a cooperação universal nos domínios da educação, do trabalho e do bem-estar gerais.

Com efeito, a exortação às soluções pacíficas será sempre platônica, enquanto não emergir de um estado de consciência resultante da cultura e capacidade de subsisitir e prosperar, a salvo de constrangimento e de ficções.

Razão por que já não são, apenas, as relações entre os Estạdos que se regem pelo direito internacional, visto que igual amparo já desfrutam os homens, sem qualquer distinção.

É o que declara e se propõe assegurar a organização das Nações Unidas, ao estatuir os direitos e deveres internacionais da pessoa humana, em cuja fixação se extremaram tantos e agitados congressos, nos quais ressoaram as franquias da Magna Carta, sete vêzes secular.

\section{UM MUNDO Só}

Menos que a mentalidade é, pois, a própria consciência de um mundo só, que se alonga e difunde entre as nações, movendo-as à reação salvadora contra o avanço da cortina de ferro, anteparo da tirania e da escravidão.

Não há civilização que, ao rigor, perdure em meio de antagonismos, como não há paz que deite suas raízes em um mundo de onde desertaram a liberdade e a justiça.

Sentem e proclamam os observadores que a terra já começa a tornar-se pequena, tanto se multiplicam seus habitantes e diminuem os víveres, ao ponto de enormes populações padecerem a inclemência da penúria e da fome.

Ora, a vida é naturalmente um direito e o trabalho è socialmente um dever, sendo a preservação de ambos a condição da sobrevivência, insusceptível de restrições.

Sem dúvida, não teve outro alvo o plano Marshall, que já foi considerado a maior iniciativa democrática do século e destinado a facilitar a ressureição econômica da Europa, propiciando a tôdas as criaturas os meios de viverem e consagrarem-se a uma atividade útil.

Fundados nesses pressupostos, que são a pedra angular da civilização, os seus líderes propugnam o fortalecimento de várias institiuções e dpilomas legais, uns e outras aplicados a estreitar as relações humanas, a conservar os recursos naturais do solo e a abrir à ciência os arranjos hábeis para produzir em proporção das necessidades crescentes.

Estão nesse caso os organismos, criados e mantidos em auspicioso e regular funcionamento pelas Nações Unidas, como ainda em

$14-$ R. D. $-3 .^{\circ}$ Vol 
projeto a organização do comércio internacional e a carta interamericana de garantias sociais.

Percebe-se assim que os vários povos, conduzidos pela intuição do destino e alertados pelos perigos envolventes, não mais se dispõem a agir isolados e dispersos, senão que procuram, nas normas jurídicas de comum observância, um estuário aberto à compreensão e segurança recíprocas.

Tanto mais profícuos, nesse sentido, serão seus esforços, quanto menos contingentes as garantias dispensadas à livre expansão das energias individuais, postas ao serviço do progresso e dignificação humanas.

\section{A DEMOCRACIA E AS LEIS}

Contudo, só a democracia poderá propiciar aos consórcios políticos, integrados de unidades conscientes, a realidade e o gôzo dé todos os direitos, que estimulam e robustecem os empreendimentos meritórios.

Debaixo dêsse sistema, que não mistifica e que não oprime, deparam espontânea acolhida, nas emergências mais diversas, tôdas as reivindicações, contanto que exprimam um anseio justo ou signifiquem uma providência tempestiva.

Nos governos que o objetivam, as leis não oscilam ao influxo do capricho, pois que refletem a pressão de necessidades inelutáveis. Reside nisso a congruência de seus textos e a oportunidade de seus fins.

"Legislar para progredir", afirma Georges Rippert, "tal é à regra que se impõem os governantes democráticos".

São de pensar igual quantos se debruçam sôbre a realidade viva e contemplam a evolução do regime, atentos, à sua prática e seguros de seus benefícios, que derivam da sobriedade e da conveniência. .

Mui diferente é, entretanto, o panorama que se desdobra sob os governos de fato, que não discernem entre as leis boas e as más; tanto se preocupam de as multiplicar, afeitos a sobressair pela autoridade sem contraste.

A proliferação legislativa encerra, naturalmente, uma série de malefícios, tendo como suas causas a redundância, a contradição, a obscuridade, que tumultuam e disturbam a ordem jurídica.

O maior detrimento que, todavia, ocasionam cifra-se, em gravitarem, como cogumelos, à margem dos códigos, cuja unidade desaparece nas investidas sem lógica e sem plano, que desencadeiam os inovadores apressados.
Tôda vez que se aconselha a refurma de certos mandamentos legais, é evidente que, em lugar da realização dela por via duma lei nova, mais convirá que o seja através de emenda à codificação existente:

Nesse particular, é bastante concludente o exemplo de diversos países, sobretudo europeus, com a Inglaterra à frente, e onde as leis se rejuvenescem, imprimindo ao repositório antigo um sôpro de plena atualidade.

Sempre que assim não acontece, a técnica legislativa desgarra de seus preceitos e se arvora em matriz de flagrantes absurdos, bafejados pela sofreguidão e demagogia políticas, que tanto conspiram em prejuízo das conștruções jurídicas.

Bem o sentia Rui Barbosa, ao asserverar que "as codificações são monumentos destinadọs à longevidade secular" e, nesse longo ciclo, não perdem jamais a sensibilidade às transformações ambientes.

E' a ocorrência imanente e dominadora, que se verifica onde quer que os fatos sociais interessam às criações do espírito e concernem as relações entre os homens.

\section{POSIÇÃO DO BRASIL}

Não há dúvida que, a despeito de país novo, já sobram ao Brasil, neste terreno, as sugestões e os exemplos que testemunham uma a diantada evolução jurídica.

Estão vasados nesse teor seus vários códigos, que assomam entre os congêneres como padrões de sabedoria e de eficiência, tanto se esmeraram seus autores em recolher e acrisolar as conquistas de alto cunho.

Mas se refletiram e condensaram as teorias então em voga, nem por isso se mostraram menos permeáveis às modificações ditadas pelo transcurso do tempo, sob o império das exigências sociais e econômicas, como o demonstrou o nosso Código Comercial, cujo centenário se festeja neste certame.

Consideráveis foram, por certo, as influências que se desatavam, especialmente durante as duas conflagrações e neste após-guerra, configurando outros rumos nos quais ganham extensão e se revestem de maior consistência os direitos e deveres humanos.

São as inovações resultantes dessa revolução mundial, consequente aos prélios cruentos e sacudida pelo apêlo à liberdade e segurança econômica, que avultam entre as máximas reivindicações do século, os materiais que demandam estudo e judiciosa acolhida nos textos legais. 


\section{O SENTIDO DO CONGRESSO}

Outra não tem sido, nos congressos jurídicos, a preocupação de seus organizadores e, conquanto nela se louvassem os promotores da presente assembléia, importa salientar que deveras a realizaram, através da conjugação de valiosos esforços de seus delegados, entre os quais se distinguiram verdadeiros e eméritos cultores do direito.

Quase não houve ramo da ciência de Ulpiano onde se não deparasse uma tese, ou uma indicação, formando algumas dezenas, que versam e discutem questões de indubitável magnitude, nos dias atuais.

Assim se explica que as controvérsias assumissem, não raro, uma feição vigorosa e ardente, que punha em realce um desencontro de opiniões, sem agressividade e sem malícia.

Mas, convinham todos, nsse empenho leal, em buscar a isenção e o acêrto, que são atributos inseparáveis de tôdas as decisões destinadas a influir e a perdurar.

A lucidez e o realismo que, dessarte, se comunicaram aos sucessivos trabalhos, múltiplos e variados, mostram que os juristas, partícipes dêste conclave, souberam onde e como situar suas conclusões.

Inteiramente se justificam, portanto, a ufania e o entusiasmo que usufrue e manifesta, nesta sessão de encerramento, o primeiro congresso jurídico do Rio Grande do Sul.

Suas diretrizes e seus resultados evidenciaram a clarividência da iniciativa e enalteceram os préstimos que à rota aprazada conferiram, ao longo de sete dias de magnífico labor, os homens do direito, que acorreram uns do estrangeiro e outros de paragens distantes do Brasil.

Nunca se contemplou, neste rincão meridional, uma afluência mais expressiva de profissionais e de mestres, enlevados e unidos pela consciência jurídica, como espelho vivo de nobres e gloriosas pelejas.

Graças a êsse ofício sacerdotal, eis que se efetuou, entre nós, uma confraternização de juristas, pois não tiveram outro sentido, neste plenário, suas relações tão gratas e seus debates tão memoráveis.

\section{GRATIDÃO QUE PERDURA}

Muito se deveu, nessse particular, às duas presidências do congresso, que possuíram como seus titulares os professores Waldemar Martins Ferreira, representante da tradicional Faculdade de São Paulo, e Júlio César Bonnazzola, docente da prestigiosa Faculdade de Buenos Aires.

Suas figuras que, à frente dos trabalhos, se destacaram pelo engenho e tato magistrais, impuseram-se à geral simpatia e sobressaíram pela erudição e equilíbrio científico.
Igualmente relevante foi a projeção intelectual, que grangearam pelas teses apresentadas, ao mesmo tempo que pela participação nas discussões, outros professôres de Buenos Aires e Montevidéu, assim como de Faculdades de nosso país.

Assinalaram-se ainda, por suas contribuições, algumas das quais notáveis, promotores e advogados do Rio Grande do Sul, todos portadores de credenciais ao aprêço e à estima de seus pares.

Em vista do apreciável e fecundo saldo, que decorreu dessa diligência, consagrada inteira ao êxito do congresso, são de merecido louvor, aos seus delegados as palavras que me cabe proferir, especialmente em nome da. Faculdade de Direito de Pôrto Algre, sob cujo patrocínio e desvelada cooperação se reuniram e trabalharam, em plena efusão espiritual, os desinteressados batalhadores da ordem jurídica. (Palmas)

O SR. PRESIDENTE - Fará uso da palavra o sr. professor Magdaleno Girão Barroso.

O SR. MAGDALENO GIRÃO BARROSO - Exmo. Senhor Presidente dêste Congresso Jurídico.

Exmos. Senhores Representantes do Exmo. Senhor Governador do Esta e de S. Excia. Reverendíssima, o Senhor Arcebispo Metropolitano.

Senhor Diretor da Faculdade de Direito.

Senhores Congressistas.

Minhas Senhoras e Meus Senhores.

Perante uma sociedade como esta, em que ao índice cultural se casa o seu elevado refinamento social, é uma temeridade a minha paco ve aceitar esta tarde, "nas últimas lavra, neste momento com que me honrou o sr. Diretor da Faculdade de Pôrto Alegre, para aqui falar em nome dos srs. reda Faculdade de Porto Alegre, para demais Estados do Brasil, eu tive uma porfia com o tempo, e lamentàvelmente, não me foi possível cumprir o protocolo de um discurso escrito. Seria possível assim, meus senhores e minhas senhoras, que a emoção, o tumultuar dos ciar uma só palavra.

Vou exprimir de u'a maneira perfeita os sentimentos, as emocões, tudo o que nos vai no espírito, diante desta magnífica solenidade. Na falta, porém, de uma palavra, pelo menos eu poderia apelar para o meu silêncio e os Exmos. Srs. Congressistas, talvez não notassem a falta da minha palavra, porque pelo menos lhes seria possível aplicar a lógica dos efeitos jurídicos do silêncio, isto é, sentir o pulsar dos nossos coracões, sentir a nossa sinceridade, tudo isto que nós também sentimos, êste refluir de sentimentos extraordinários que nos comovem, que nos irmanam, em função dêsses dias de trabalho, ide vida íntima, 
de "téte-a-tète" cultural, em que pudemos cada vez mais nos conhecer e admirar e em que, realmente, levamos a efeito uma contribuição em favor da cultura jurídica nacional.

A tarefa que me foi cometida é, sem dúvida, grave é severa e confesso que, ao aceitá-la, não medi bem a responsabilidade que assumia, porque me deixei levar mais pelo entusiasmo e pela honra de vir nesta tribuna representar os meus ilustres colegas das Faculdades do país. Mas, eu vim como um soldado que vai para a batalha cumprir com o seu dever indeclinável. O soldado sabe, que, talvez, Ihe faltem as fôrças, que a sua coragem venha a fraquejar, que o. seu próprio vigor físico não possa corresponder, na medida de seus desejos, à sua tarefa; mas, apesar de tudo isto, êle não se acovarda, toma as armas e avança para a trincheira. $E^{\prime}$ o que estou procurando fazer, meus ilustres colegas, com o mesmo espírito do soldado, porque nós também somos soldados do Direito e é a êste espírito que nós estamos dando u’a magnífica contribuição neste Congresso, porque o Direito, creio eu, é sobretudo uma fôâa neste Congresso, porque o Direito, creio eu, é sobretudo uma fôrça incoercível que vem do mais íntimo do sêr, que não podemos bem definir, mas que sentimos que sempre esteve em nós, em todos os momentos da vida, que sempre esteve em nós, em todos os momentos da História. O homem primitivo, o homem da caverna já sentia o da Historia. êsse direito vem acompanhando a direito Quando o homem descobriu om todos os tempos. niram em ón quando homens se niram em tôrno da primeira lareira, êles já começaram a criar o Direito, já começaram a organizar a sociedade, porque, como diz o provérbio latino, "ubi societas, ibi jus".

Mais tarde, o homem evoluiu, mas evoluiu, sempre com o direito. Nos tempos antigos, na Grécia, dotada de grande sabedoria filosofica, entre os romanos, dotados de espírito pragmático, e que nos deram êsse grande edifício da juridicidade do Código Justiniano; na Idade Média, na Idade Moderna, e em todos os Justiniano; na dias, nós vemos que cada vez mais precisamos, necessitamos dêsse elemento jurídico, que é intrínseco à nossa personalidade e sem o qual nós não podemos, absolutamente, organizar e fazer viver a comunhão social.

Já o afirmou um filósofo norte-americano, que, nos tempos atuais, a sociedade talvez não resistisse ao impacto da ciência, isto é, que a ciência está criando, para o mundo atual, tais fatôres de complexidade orgânica, tais transformações de natureza material que talvez não fôsse possível à ética, ao direito, portanto, acompanhá-la nesse evolver tão rápido e tão inusitado. E, assim, temia êsse filósofo norteamericano que, de um momento para outro, viesse a sociedade a voltar ao cáos de onde viera, por efeito de fôrças físicas, de fôrças naturais, despertadas e em eclosão sôbre a sua realidade.
Quero crer que, ao afirmar isto, o seu autor estivesse porventura impressionado com as invenções mecânicas e os grandes produtos da física moderna, sobretudo da física nuclear e da física intra-atômica, pois que esta, como nós sabemos, criou o problema formidável que diz muito de perto com a nossa sobrevivência ou com a nossa morte, $e$ pôs, nas mãos dos homens, talvez não moralmente e suficientemente preparados para isso, uma arma que poderá fazer tôda a sua felicidade ou tôda a sua desgraça.

Como, então, meus senhores, acompanharemos êsse evolver da sociedade e conseguiremos que ela resista a êsse avanço formidável das ciências naturais, em face de um certo atraso das ciências éticas e sociais? Só é possível, por meio do Direito. Só pelo Direito, quero crer, poderemos realizar a transformação social de que nós necessitamos para o asseguramento da sobrevivência do mundo de hoje. (Palmas).

$E^{\prime}$ verdade que contra esta tendência, que está no espírito de todos os verdadeiros juristas e de todos os amantes do jus, manifestam-se, na atualidade, muitas fôrças, muitos fatôres que é necessário vencer, mas nós para isto precisamos ter o espírito forte, pelo menos aquêle espírito que nunca abandonou o grande filósofo alemão Kant e que, sob o efeito da tirania, chegou a afirmar: eu nunca disse tudo o que queria, mas pelo menos, nunca disse o que não queria. Se nós não pudermos dizer tudo o que queremos, se não pudermos manifestar integralmente o nosso pensamento, pensamento de liberdade, dé Direito, de justica, de paz, pelo menos nós não devemos dizer o que não queremos. Não devemos concordar com a tirania, com a guerra, não devemos aceitar o pessimismo do momento atual, porque só assim poderemos vencer a crise de civilização, de progresso, a crise verdadeiramente fundamental em que nos encontramos na atualidade. E uma das contribuições para isto é, justamente, êste Congresso, que teve por objetivo congregar homens de pensamento, juristas dos vários quadrantes da nacionalidade e não sòmente dela, mas também dos países vizinhos, para o fim de, mais uma vez, cantarem um hino de supremacia e glória ao Direito e nêsse hino externarem suas idéias e manifestarem livremente, dentro de um ponto de vista prático, o seu ponto ed vista, criarem ou consolidarem as doutrinas filosóficas e jurídicas, para não deixarem que a cincia jurídica pare, mas, pelo contrário, evolua cada vez mais, em busca dos seus grandes objetivos, dos seus grandes ideais.

Êste Congresso, meus senhores, foi realmente uma demonstracão magnífica, extraordinária, rara mesmo, de confraternização cul tural, de irmanação, de entendimento, de compreensão afinal de contas, onde todos nós, ém contato uns com os outros, aprendemos alguma cousa de novo, quer do ponto de vista pròpriamente cultural jurídico, 
da ciência que amamos, quer do ponto de vista social, quer do ponto de vista nacional ou internacional, porque a geografia que nos separa é pela experiência dêsses congressos, pelo contato que acabamos de estabelecer, uma geografia que nos une, porque só assim poderemos aquilatar que as fôrças que dormem isoladas em cada um de nós, quando irmanadas, unidas, removem montanhas. (Palmas).

Eu estou falando em nome de todos os congressistas dos Estados do Brasil aqui representados, Estados do norte, Estados do sul e Estados do centro. Todos êles. E' possível que a minha palavra não exprima bem o pensamento, todos êles estão perfeitamente de acôrdo com os altos objetivos dêste Congresso e de acôrdo em que êle colimou, realmene, de u’a maneira belíssima e incontrastável, todos seus elevados objetivos. Porisso, merecem louvores os membros da Congregação da Faculdade de Direito de Pôrto Alegre, da Universidade do Rio Grande do Sul, que organizaram êste magnífico conclave, especialmente o Ilmo. Sr. professor Salgado Martins, que, de modo tão brilhante, conduziu nossos trabalhos. (Palmas).

Quero chamar a atenção, também, para a contribuição de todos os senhores professores dêste Estado e tenho que felicitar o Rio Grande do Sul e felicitar esta sociedade, por contar em seu meio com uma plêiade tão brilhade, tão vigorosa, tão cehia do espírito de de ver, como essa de que fui testemunha e que compreende os juristas desta Faculdade. Levo, e creio que todos nós dos outros Estados levamos, uma indelével impressão pela maneira como todos êles se desincumbiram de sua tarefa, de modo equilibrado, demonstrando uma cultura superior e, sobretudo, externando pontos de vista, quer dentro do direito objetivo, quer dentro do direito filosófico e político, externando pontos de vista que são os mais oportunos, os mais interessantes e mais dignos da aceitação geral.

Ao falar em nome dos Srs. congressistas de todos os demais Estados, eu me sinto verdadeiramente à vontade e desejaria que, através de minha voz, repercutisse, de maneira integral, tudo aquilo que êles " poderiam pessoalmente expressar. Entretanto, a vossa sensibilidade, srs. congressitas, meus senhores e minhas senhoras, haverá perfeitamente de preencher as lacunas da minha palavra, reconhecendo tudo isso que não pude exprimir, nem dizer.

Resta-me apresentar as nossas despedidas, despedidas que não são um adeus, porque representam antes um traço de união, que nos congregará daqui por diante, pelo pensamento, pela idéia, em função do Direito e, ao mesmo tempo, formular as nossas congratulações a $S$. Excia. o Sr. Diretor da Faculdade re Pôrto Alegre, ao Sr. Presidente do Congresso, aos demais congressistas e ao Rio Grande do Sul em geral, pelo brilhante êxito dêste conclave. (Palmas).
O SR. PRESIDENTE - Se algum dos senhores congressistas quiser nos honrar com a sua palavra, para expressar seu pensamento, apresentar alguma sugestão ou externar alguma idéia, esta Mesa terá muito prazer em the conceder a palavra. (Pausa).

O SR. JULIO BONAZZOLA.

Exmo. Sr. Vice-Presidente dêste Congresso Jurídico.

Exmo. Sr. Representante de S. Excia. o Sr. Governador do Estado.

Exmo. Monsenhor Representante de S. Excia. Rvma. o Sr. Arcebispo Metropolitano.

Exmos. Magistrados da Justiça.

Exmos. Srs. Congressistas.

Senhoras.

Senhores.

Meus queridos alunos.

Conta uma lenda árabe que as flores de um jardim murcharam quando o jardineiro que as havia cuidado se afastou do lugar. Assim foi que as hastes esguias das brancas magnólias se quebraram, como minaretes de alabastro; que as rosas cerraram suas pétalas como cerram-se os negros olhos da mulher amada; os níveos cálices das flores se fecharam como a noite e os jasmins caíram como mãos extenuadas pelo trabalho. Esta parábola, senhores, muito conhecida na lenda árabe, tivemos a sensação de viver neste Congresso, quando o eminente professor Waldemar Ferreira, chamado por suas tarefas, afastou-se do nosso lado e nós tivemos a impressão de que o jardim dêste Congresso Jurídico também havia murchado, como as flores do jardim da lenda árabe. Mas o esplendor das idéias sobrepuja a matéria humana, é o signo da fé que, sem dúvida, sobrepaira, como gorjeios de pássaros, nas raízes do nosso pensamento, para torná-lo cada vez mais brilhante. E o professor. Waldemar Ferreira está presente no nosso espírito e para êle peço entusiástica salva de palmas. (palmas prolongadas).

Numa noite de emoção, não posso tampouco deixar de expressar o quanto senti nesta cidade, tão semelhante aquela que cantei em minha prosa e em meus versos íntimos. Quero cantar também a esta Faculdade de Direito de Pôrto Alegre que, com tanta dignidade, representa êste querido decano, dr. Salgado Martins.

A Faculdade de Direito de Pôrto Alegre poderia significar um exata paralelo com a Faculdade de Direito de Santa Fé. Também a Faculdade de Direito de Santa Fé, sr. Diretor, faz pouco 'tempo cumpriu 50 anos de existência e, naquela cidade, que nós chamamos "a cidade das lousas e das pedras", também floresceu, como nesta, um resplendor de idéia jurídica que surgiu pouco a pouco e que já completou um cinqüentenário, que nós celebramos com o mes- 
mo entusiasmo com que estamos celebrando o cinqüentenário da fundação da Faculdade de Pôrto Alegre.

Existe outra homenagem mais esta noite: é a homenagem ao centenário do Código Comercial. As teses apresentadas pelos diversos professores no sexplicam a razão de ser de sua vitalidade. A vitalidade do Código de Comércio está em dois pontos fundamentais: em ter respeitado os usos e costumes locais em seguir a trajetória dos mesmos e em ter esperado, como diz o professor Estrella, que as reformas se fizessem com método e precaução.

Quero comparar, senhores, como se estivesse numa aula amável de todos os dias, com os alunos, as fontes diversas que temos em nossa legislação, pela qual podemos, os países sul-americanos, ter orgulho de latinidade.

Eu queria fazer, se me permitissem, sr. Vice-Presidente, um pequeno relatório de confronto entre as fontes das legislaçoes e a fonte das demais legislações européias e norte-americana. A fonte jurídicofilosófica da Alemanha está inspirada no matematicismo jurídico. A perfeição de suas ciências exatas chegou a fazer pensar, aos seus tratadistas do direito, que o Direito poderia ser contemplado em fórmulas que aproximassem também do matematicismo das ciências exatas. $\mathrm{Pa}$ rece que se esqueceram do pensamento de Justiniano, quando dizia que o orador jurídico e o jurista devem conhecer muito bem a lei devem conhecer muito bem a vida. O jurista não pode encerrar-se na tôrre de marfim da completa indiferença à vida que passa. Tampouco poderemos, senhores, inspirar-nos na legislação inglêsa, baseada no direito consuetudinário, onde se conservam ainda normas do tempo de João sem Terra, do ano de 1200; uma legislação que mantém ainda a determinação de prisão por dívidas, abolida de nossos princípios políticos, como uma das normas imanentes da liberdade do homem sôbre a terra; uma legislação, finalmente, onde as reformas nem sempre são possíveis, frente aos erros, porque a escola inglêsa sustenta que "se está escrito, está bem escrito".

Como poderemos inspirar-nos na legislação norte-americana, eminentemente casuística, onde os advogados e professores não têm nenhum sistema para conhecer quais são os princípios jurídicos genéricos, que inspiram as resoluções de seus pensamentos?

Para o jurista norte-americano, todos os problemas se resolvem com os casos. Para nós, todos os porblemas devem resolver-se por princípios, porque os princípios, no Direito, muitas vêzes são imanentes.

Como poderemos inspirar-nos, também, na legislação francesa, que tanto serviu de modêlo à nossa?

Não queria recordar aos senhores, para não cansá-los, tôda a história do chamado "direito intermediário"; que vai do iluminismo, desde os enciclopedistas, até a codificação do direito francês.
Conseguida a unidade política da França, em 4 de Agôsto de 1789, assegurada pela Convenção a unidade territorial e política, restava àquele país a necessidade de uniformizar a sua legislação civil. No sul pontificava a influência do Direito Romano. No centro e norte da França, predominavam as normas contraditórias do direito consuetudinário, e regulavam as normas territoriais do direito feudal, as Ordenações inaplicáveis, as Ordenações do Rei, e a longa formação e ensinamentos, sempre permanentes, do direito eclesiástico.

O Brasil e a Argentina têm como fonte comum a inspiração peninsular: as Ordenações Filipinas, de Filipe II, imperaram no Brasil e tiveram sua influência no que é hoje meu país. Estamos irmanados numa mesma latinidade, e eu me sinto perante vós como entre irmãos de sempre e vos posso dizer, sem nenhum laivo de vaidade, que, com muita tranqüilidade, eu poderia dar minhas aulas de Direito na Faculdade de Direito de Pôrto Alegre, com a mesma tranqüilidade de espírito e o mesmo prazer com que o faço nas aulas universitárias de meu país; e temos de comum até os nossos rios; os nossos caudalosos rios como o Paraná, que nasce no Parimá, no grande maciço atravessa regiões do Brasil e vem fecundar as costas argentinas, nas águas dos istmo, onde nós cantamos com San Martin, em 1813, as páginas gloriosas da liberdade, e, no delta do Rio da Prata, e, nas correntes cálidas dêsse mar, volta a banhar outra vez as costas fecundas do Brasil; por que, senhores, se há esta identidade antropológica e social, que tanto têm descrito vossos autores, não podemos aspirar e permitir a pretensão de ver vitoriosa a proposição que irei fazer diante de vós?

Vou permitir-me, antes dessa proposição, recordar não uma parábola, mas um fato histórico. Contam, que numa tarde de outono, sôbre o fundo brumoso de Paris e a gaza aveludada da praça da Concórdia, ao entardecer tranqüilo e ameno, passeava pelos jardins uma senhora, uma anciã, amparada em um bastão, seu cabelo encanecido, um pouco curvada, denotando certa distinção e dignidade da aristocracia. Depois de caminhar pelo jardim, com alguns titubeios, aproximou-se de uma rosa e admirou-a com enlêvo, com tanto enlêvo, que se aproximou para, tomando-a entre as mãos, beijá-la. Naquele momento um guarda do jardim lhe disse: - Senhora, é proibido tocar nessa rosa, porque é a rosa de Espanha". Ergue-se a senhora e, com os olhos marejados de lágrimas, disse-lhe: "Eu plantei esta rosa. Sou a rainha-mãe de Espanha e vim ver como tinha florescido".

Pois quisera eu, como a rainha-mãe de Espanha, aqui lançar também uma semente, para, num dia outonal e já tão envelhecido quanto ela, poder vir vê-la e beijá-la nesta cidade de Pôrto Alegre. (Palmas).

Por que, senhores, se temos esta tradicão comum, por que não fazemos, como dizia há pouco o professor Girão Barroso, com que o 
Direito nos una - porque o Direito é a vida - e não pensamos, senhores, em fazer um Código de Comércio único do Brasil e da Argentina? (Palmas).

E' esta uma noite de homenagem, é uma noite de emoção.

Com uma emoção que me $\mathrm{faz}$ ir quase às lágrimas, devo acrescentar que esta noite é também a do centenário da morte do Genera San Martin e vou usar da vossa benevolência, nesta noite de homenagens, para traçar um breve perfil de San Martin. San Martin foi um dos poucos soldados sôbre a terra, cuja espada não se utilizou jamais para conquistar, mas para libertar os povos. A espada flamejante de San Martin serviu para abrir sulcos fecundos na terra dura da América. Sua disciplina anterior, formada nas casernas da Espanha, permitiu-lhe voltar às terras da América e substituir os "montoneros", os gaúchos e a ferocidade, pela disciplina que tudo consegue c tudo organiza. Assim foi que um dia dirigiu-se a Mendoza, para fazer a campanha libertadora do norte. E sua obra, meus senhores, foi compreendida primeiro e apoiada primeiro pelas mulheres. As mulheres ajudaram-no a fazer a roupa para os seus soldados, as mulheres bordaram, em fios de filigrama de ouro, o sol dourado de sua bandeira. E a despedida de San Martin da praça de Mendoza parecia aquelas despedidas de epopéia, onde os heróis insignes, ao se despedirem, juravam por seu rei e suas damas. $\mathrm{E}$ assim foi que escalou os Andes, os mais altos cumes do mundo, desde o dia glorioso de Maipú, depois do desastre de Cancha Rayada, ressonando os clarins para chegar em frente ao seu batalhão. Foi assim, que um dia conseguiu escalar o Tupungado, para travar a batalha de Chacabuco, como querendo buscar, nas mais altas montanhas do mundo, a forma pela qual seus soldados se aproximassem tanto de Deus, para arrancar o azul e o branco e o sol para a nossa bandeira. E assim conseguiu libertar o Chile.

Logo veio a campanha difícil do Perú, onde, caminhando entre os frios desfiladeiros das montanhas, marchando com os soldados fatigados, com suas mulas, à maneira de Napoleão, quando subiu ao São Bernardo, mas sem imitá-lo e com fins distintos, porque ia libertar outro país, chegou ao Perú e o povo o aclamou e êle declarou, em nome da expedição libertadora, em 27 de novembro de 1820 , a liberdade do Perú.

Mas a grandeza de um homem nunca se vê no triunfo. Todos somos grandes, frente ao triunfo, todos nós nos sentimos cheios de valor, quando temos êxito e sucesso em nossas emprêsas. Já o adverte Kant, quando diz que "nunca tenhas demasiada fé para ser vaidoso e nunca tenhas demasiada desesperança para crer que tua esperança não se vá cumprir".

E San Martin, demasiadamente glorioso por suas batalhas e seus exitos, retirou-se de seu páís, para que sua espada vencedora não influísse na organização política da Argentina.

Foi grande na renúncia. Pobre e sem recursos até o dia de seu falecimento, em 17 de agôsto de 1850, quando, às três horas da tarde, o surpreendeu a morte.

$\mathrm{E}$, quem havia de dizer que, cem anos depois, fizesse eu esta oração! Com a devida vênia, do nobre sr. Presidente, pediria a êste Congresso que fizesse um segundo de silêncio, em sua homenagem.

(Os Congressistas, de pé, prestam a homenagem).

Para terminar, devo expressar meus agradecimentos, porque esta noite é de festa e emoção.

Devo agradecer ao senhor Diretor da Faculdade, professor Salgado Martins, a quem não sei se admirar mais a enorme bondade que teve para conosco, ou admirar mais o acêrto com que dirigiu as deliberações dêste Congresso.

Quero expressar, também, a grande admiração científica que me produziu o professor Ernani Estrella, que me ocorre dizer que é um Savonarola do Direito.

Quero, também, expressar minha admiração científica pelo $\mathrm{dr}$. Antônio Martins Filho, que com tanta fé - porque só a fé move - e convicção logrou vitória na defesa de sua tese, em que votei, e que tanto admiro.

Quero expressar, também, a minha simpatia pelo sr. Diretor da Faculdade de Direito de Pelotas, professor Bruno de Mendonç Lima, pois, me ocorre pensar que o professor Bruno de Mendonça Lima tem a bondade infinita dos bem-aventurados, que jamais há uma sombra de suspeita nêle, ainda que isso pudesse turvar-lhe a alma.

Quero expressar, também, minha admiração pelo dr. Luiz Lopes Palmeiro, e não sei se seu nome nasceu no Renascimento, ou se êle é uma figura que se move em Versailles.

Quero expressar, também, minha admiração pela consciência jurídica de todos os demais professores, pelos eminentes juízes e ma gistrados, que até me fazem pensar na Carta de São João, quando diz: "Não há pobres, nem ricos; não há grandes nem pequenos; todos são iguais ante Deus".

Parece-me que vós, juízes, também tendes êste sentido eminente da Justiça, porque sentís que todos são iguais ante a lei.

Aos integrantes das comissões que trabalharam com entusiasmo, ao sr. Secretário, tão cheio de cortesia, dr. Plauto Azevedo, e às demais pessoas que não menciono por falta de memória, posso assegurar que admiro em cada uma delas as suas virtudes humanas.

E por último, exmas. autoridades, minhas senhoras, meus senhores e meus alunos, quero agradecer-lhes tôdas as atenções imerecidas, 
que expressar-lhes que quando os srs. visitarem a minha populosa cidade de Buenos Aires, ou cálida e ingênúa cidade de Santa juntos a cidade, para sentir juntos as mesmas emoções.

Quero formular votos para que as nossas relações sejam cada vez mais fortes, para que a nossa fé e entusiasmo sejam cada vez mais estreitos, para que a nossa estrêla de idealismo se levante cada vez mais serena e dizer como Horácio: "Nem tudo morre". (Palmas),

O SR. SALGADO MARTINS - Antes de declarar encerrada a sessão que põe têrmo aos trabalhos dêste conclave, sinto o honroso dever de, em nome da Comissão Organizadora do Congresso Jurídico, comemorativo do cinqüentenário de fundação da Faculdade de Direito, agradecer aos eminentes professores, advogados, juristas, magistrados, a todos aquêles que trouxeram o brilho do seu concurso para assegurar o êxito do empreendimento cultural que realizamos.

Tudo neste dia se reúne para acentuar a nossa emoção. Duaś gerações confraternizam, neste momento de tanta evocação para a história da Faculdade de Direito de Pôrto Alegre: a geração gloriosa que fundou esta escola e a geração dos seus professores que comemoram o cinqüentenário.

Temos a ventura, a inigualável fortuna de contar ainda com professores que fundaram esta Escoal e que aqui assistem o seu cinqüentenário. Entre nós, temos a felicidade de contar com a presença de um mestre venerando, o ilustre professor Normélio Rosa... (De pé, a assistência saúda com prolongada salva de palmas o professor Normélio Rosa, que agradece comovido)... o professor Normélio Rosa, no qual eu personifico tôda aquela plềiade de lutadores que fundaram esta casa de ensino superior, no ano já remoto de 1900 .

Quero, também, lembrar o nome daqueles que ainda assistem o transcorrer desta data significativa, os professôres Plínio de Castro Casado, James Darcy e Valentim do Monte.

Nêles pulsa, ainda, com tôdas as suas glórias, a história desta Faculdade.

O Congresso Jurídico que promovemos realizou-se entre duas datas nas quais se descobre uma perfeita identidade e um tocante signo de idealismo. Iniciamos os nossos trabalhos a 11 de agôsto, desta comemorativa da fundação dos cursos jurídicos no Brasil, e encerramos êste Congresso em 17 de agôsto, data que recorda o centenário da morte de uma das figuras mais extraordinárias da América, o herói e libertador San Martin. (Palmas prolongadas).

Onze de agôsto é o signo da consciência jurídica do Brasil e a espada de San Martin é o instrumento glorioso através do qual vários países da América encontraram a sua libertação e a sua redenção. (Palmas).
Onze de agôsto é a concretização de uma idéia generosa, porque representa os fundamentos do ensino jurídico no Brasil; dezessete de agôsto recorda uma vida que, pela espada, realizou a sublimidade do Direito. (Palmas).

Devo expressar, ao término dos trabalhos dêste Congresso, os agradecimentos comovidos da Faculdade de Direito, pêlo concurso que as delegações das diversas Faculdades trouxeram ao êxito dos seus trabalhos.

Em primeiro lugar, agradeço a cooperação generosa e brilhante que nos deram as gloriosas Faculdades de Direito de Buenos Aires e de Santa Fé, (Palmas) enviando-nos, para representá-las neste certame de inteligência e cultura, a figura fidalga e amiga do professor, Jútio César Bonnazola. (Palmas). Ele, agora, não pertence às Faculdades que representa. E' mais um professor que conquistamos. (Palmas). A sua atuação, a simpatia com que se incorporou à história desta Faculdade, será perenemente um traço de união entre o Brasil, o Rio Grande do Sul e a generosa nação Argentina. (Palmas).

Quero agradecer à Faculdade de Direito do Ceará, (Palmas). O gesto com que nos distinguiu, enviando, para representá-la, dois professores eminentes de sua Congregação, cujo nome declino com profunda simpatia, os profesosres Antonio Martins Filho e Madgadelo Girão Barroso. (Palmas)

Devo agradecer à Faculdade do glorioso Estado Irmão de Santa Catarina, que se fềz, também, representar neste Congresso, pela brilhante delegação, em que figura um ilustre professor de Direito, Henrique Rupp Júnior (Palmas), filho espiritual desta Casa e representante daquela gloriosa geração que foi contemporânea da fundação desta Faculdade.

Devo agradecer à Faculdade de Goiás, a distinção, também, que nos conferiu, através da representação que delegou ao ilustre professor Antônio Martins Vieira, (Palmas), que contribuiu magnificamente para o acêrto das nossas decisões.

Devo agradecer à tradicional Faculdade de Direito de São Paulo, berço glorioso do ensino jurídico no Brasil, escola que contribuiu tão decisivamente, com o ensino do Direito, para preparar diversas gerações que foram valores decisivos na história política, jurídica e espiritual do país.

Devo agradecer à Faculdade do glorioso Estado irmão de Santa ela nos mandou para representá-la neste Congresso e para presidir os seus trabalhos, uma das mais eminentes expressões do magistério jurídico, a figura ímpar de Waldemar Ferreira. (Palmas). Devo agradecer à Faculdade irmã de Pelotas, (Palmas) pela delegação brilhante que nos enviou e cujos méritos, talentos e virtudes eu quero personi- 
$-1108-$

ficar, nessa figura eminente de professor e de jurista, que é Bruno de Mendonça Lima. (Palmas).

Agradeço, por fim, ao ilustre presidente do Tribunal de Justiça, um dos presidentes de honra dêste Congresso, a honra que lhe conferiu, ao comparecer à sua inauguração e à sessão de encerramento dos nossos trabalhos, (Palmas), exemplificando, com a sua presença, que advogados, professôres e juízes estão irmanados no mesmo ideal e servindo à mesma causa.

Quero agradecer ao Exmo. Sr. Governador do Estado, pela distinção e bondade com que procurou corresponder ao convite que the endereçámos para ser um dos presidentes de honra dêste Congresso, e para trazer à sua inauguracãa o concurso do seu prestígio e da sua inteligência. (Palmas).

Agradeço às autoridades do Estado, aos senhores magistrados, membros do Ministério Público, advogados e posso declarar com orgulho que, se não fôra a simpatia e o concurso que deram a êste Congresso, não teríamos obtido o êxito com que coroamos os nossos trabalhos. $\mathrm{E}$ ao solicitar ao eminente professor Bonnazzola que declare encerrada a sessão, quero apenas dizer que os professôres desta Faculdade, no ano do seu cinqüentenário, prometem tudo porfiar, para serem herdeiros e sucessores dignos daquela obra gloriosa que os companheiros de Normélio Rosa realizaram no Rio Grande do Sul.

(Palmas prolongadas).

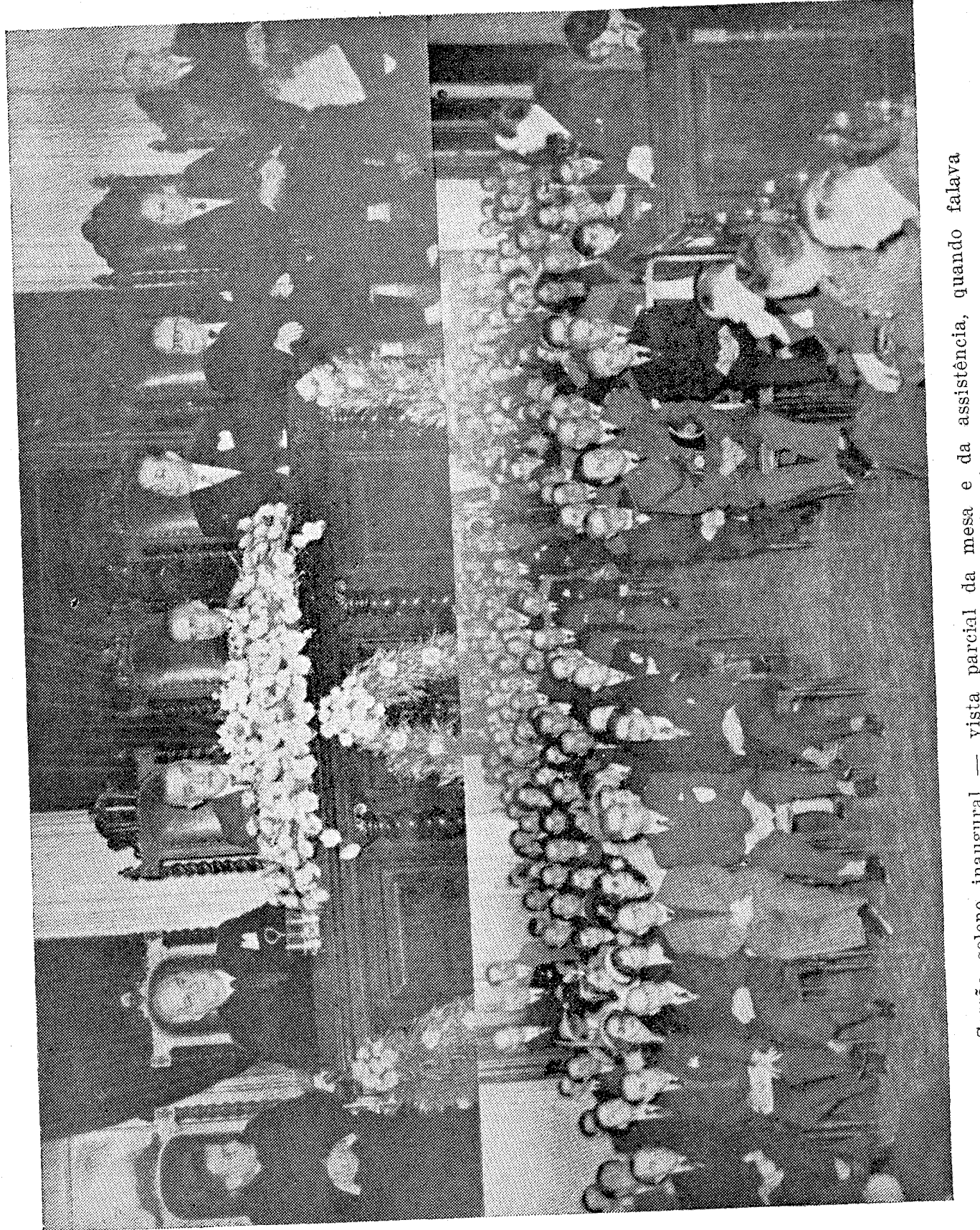

